Agr. Biol. Chem., 38 (1), 117 120, 1974

\title{
Gel Filtration of Human Casein on Sephadex G-200
}

\author{
Taro Nagasawa, Isao Kiyosawa, Kunisuke Kuwahara \\ and Yuko Inomata \\ Central Research Laboratory, Morinaga Milk Industry Co., Ltd., Tokyo \\ Received August 1, 1973
}

\begin{abstract}
Human casein was separated by gel filtration on a column of Sephadex G-200 with $0.1 \mathrm{M}$ Tris buffer ( $\mathrm{pH} 8.5$ ) containing $1.0 \mathrm{M} \mathrm{NaCl}$. The eiffuent which increased in turbidity at $25^{\circ} \mathrm{C}$ was centrifuged at $25,000 \times g$ for $30 \mathrm{~min}$ and the precipitate was obtained as Fraction 6 . After centrifugation, the effluent was separated into 5 clution fractions.

Disc gel electrophoretic patterns of each fraction showed occurrence of secondary bands other than major bands especially in Fractions 3,4 and 5. The casein solutions unheated and heated at $100^{\circ} \mathrm{C}$ for 5 and $10 \mathrm{~min}$ were kept at $5^{\circ} \mathrm{C}$ for 5 days. No marked changes of electrophoretic pattern were observed among these casein solutions. However, when a casein solution heated at $100^{\circ} \mathrm{C}$ for $5 \mathrm{~min}$ was chromatographed under the same condition, secondary bands also appeared.
\end{abstract}

Groves and Gordon ${ }^{1}$ chromatographed human casein on DEAE cellulose column and found that a single protein, containing up to 0 to 5 atoms of phosphorus per molecule, made up the major portion of human casein. $\mathrm{Na}$ gasawa et $a l .^{23}$ reported that enzymic dephosphorylation of human $\beta$-casein $\mathrm{A}$ was accompanied by the appearance of several bands with lower mobilities.

Furthermore, a number of faster moving bands other than the six major bands in human casein were observed in bovine $\alpha_{\mathrm{s}}$-casein region by gel electrophoresis. ${ }^{3 \sim 5}$, When a casein solution prepared from human milk immediately after its collection was incubated at $37^{\circ} \mathrm{C}$, fast-moving bands also appeared. ${ }^{6}$ '

This paper describes appearance of secondary bands other than major bands when a human casein solution was chromatographed in a column of Sephadex G-200.

\section{MATERIALS AND METHODS}

Preparation of human casein solution. Normal human milk was collected from healthy women after about one month of lactation. After its collection, the milk was defatted by centrifugation at $1000 \times g$ for $30 \mathrm{~min}$ at $21^{\circ} \mathrm{C}$ to $25^{\circ} \mathrm{C}$. Eighty milliliters of human skimmed milk were adjusted to $\mathrm{pH} 4.6$ with $2 \mathrm{~N}$ $\mathrm{HCl}$ and the mixture was kept overnight at $5^{\circ} \mathrm{C}$. The suspension was centrifuged at $25,000 \times g$ for $30 \mathrm{~min}$, and the precipitate dissolved in $10 \mathrm{ml}$ of $0.1 \mathrm{~m}$ Tris buffer $(\mathrm{pH} 8.0)$. The casein solution prepared was immediately used for gel filtration on a column of Sephadex G-200 and disc gel electrophoresis of casein. Casein solutions heated at $100^{\circ} \mathrm{C}$ for 5 and $10 \mathrm{~min}$ were also prepared for these experiments.

Sephadex gel filtration. Gel filtration on Sephadex G-200 (Pharmacia, Uppsala, Sweden) was performed using $0.1 \mathrm{M}$ Tris buffer (pH 8.0) containing $1.0 \mathrm{M} \mathrm{NaCl}$ as the eluting buffer. Gel column was prepared by pouring the gel particles in the buffer solution to give a bed height of $90 \mathrm{~cm}$ by $2.5 \mathrm{~cm}$ diameter. A Sephadex flow adaptor was fitted to the top of the column. The casein solution was applied to the bottom of the column and then a solvent reservoir was connected to the bottom of the column. The column was eluted upward with the buffer solution and a flow rate through the column was kept at about $10 \mathrm{ml} / \mathrm{hr}$. The effluent was collected in $9 \mathrm{ml}$ fractions with a fraction collector (Toyo Industry Co., Ltd., Model SF-200A) and the absorbance of protein was estimated spectrophotometrically at $280 \mathrm{~nm}$. To remove salts of pooled effluent fractions, gel filtration was performed by using a column of Sephadex G-25 $(5 \times 40 \mathrm{~cm})$. Desalted effluent of each fraction was pooled and freeze-dried. All the experiments were done at $5^{\circ} \mathrm{C}$.

Disc gel electrophoresis. Disc gel electrophoresis of human casein was performed as described by Nagasawa et al ${ }^{61}$

Chemical analyses, Nitrogen content was determined by a micro-kjeldahl method and phosphorus by the method of Allen. ${ }^{71}$ Sialic acid was determined 
by the thiobarbiturate method of Warren ${ }^{81}$ as a standard of $n$-acethylneuraminic acid.

\section{RESULTS}

The result of gel filtration of a human casein solution on a column of Sephadex G-200 is in Fig. 1. The effluent in the points indicated with dotted line increased in turbidity at $25^{\circ} \mathrm{C}$, but became clear when the solution was kept at $15^{\circ} \mathrm{C}$. The absorbance pattern in all other points was similar to that at $15^{\circ} \mathrm{C}$.

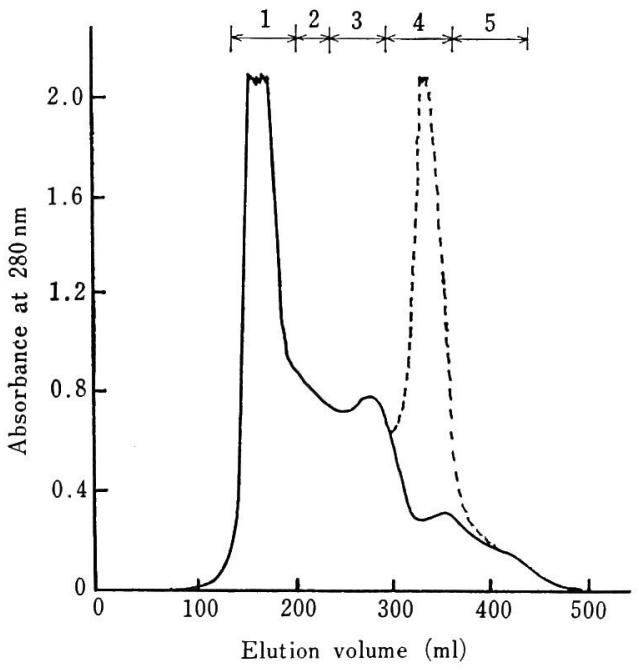

FIG. 1. Elution Pattern Obtained by Gel Filtration of Human Casein in a Column of Sephadex G-200 at $5^{\circ} \mathrm{C}$.

Solid and dotted lines indicate the absorbance of $280 \mathrm{~nm}$ at 15 and $25^{\circ} \mathrm{C}$, respectively. The vertical lines indicate demarcation of pooled samples.

Table I. Nitrogen, Phosphorus and Sialic Acid Contents of Each Fraction in Fig. 1 $(\mathrm{g} / 100 \mathrm{~g})$

\begin{tabular}{ccccc}
\hline $\begin{array}{c}\text { Fraction } \\
\text { No. }\end{array}$ & $\begin{array}{c}\text { Yield }^{a}(\%) \\
(\%)\end{array}$ & Nitrogen & \multicolumn{3}{c}{$\begin{array}{c}\text { Phosphorus Sialic acid } \\
(\mathrm{g} / 100 \mathrm{~g})\end{array}$} \\
\hline 1 & 50.3 & 13.3 & 0.30 & 1.04 \\
2 & 14.5 & 13.0 & 0.31 & 0.32 \\
3 & 17.5 & 13.1 & 0.38 & 0.34 \\
4 & 10.7 & 11.8 & 0.18 & 0.12 \\
5 & 2.3 & 11.7 & 0.97 & 0.11 \\
6 & 4.7 & 13.8 & - & - \\
\hline
\end{tabular}

a) Yield is expressed as percentage of total material recovered.

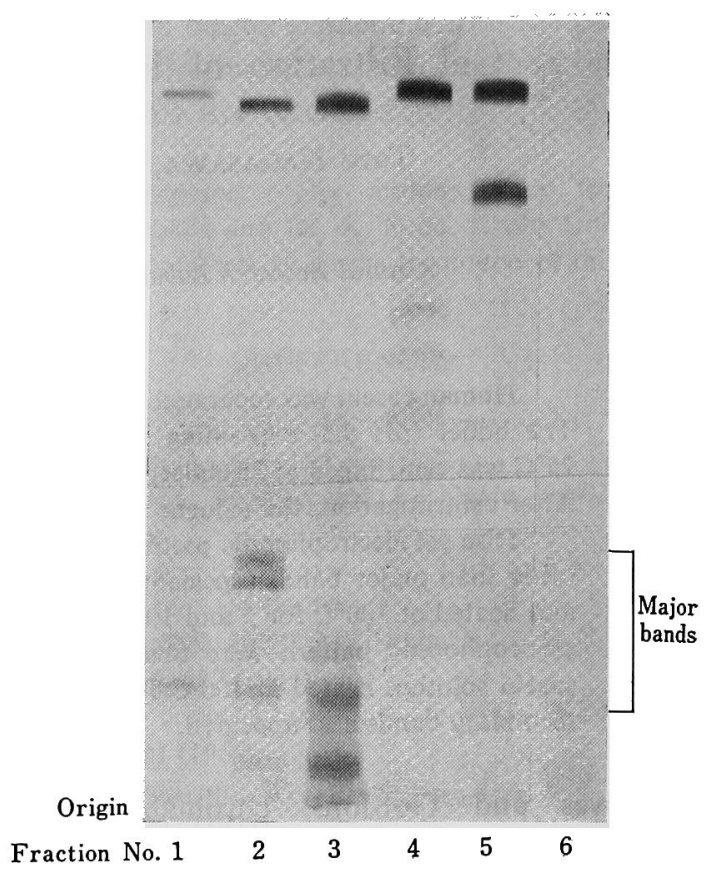

FIG. 2. Disc Gel Electrophoresis ( $\mathrm{pH} 9.4,4$ м urea) of Human Casein Fractions Eluted from Sephadex G-200.

The run was done at room temperature for $4 \mathrm{hr}$. Amido black $10 \mathrm{~b}$ stains.

The effluents with increased turbidity in each tube were centrifuged at $25,000 \times g$ for $30 \mathrm{~min}$ at $25^{\circ} \mathrm{C}$. The precipitate obtained was dissolved in cold water and freeze-dried (Fraction 6). After centrifugation, human casein was separated into 5 elution fractions (Fraction $1 \sim 5$ ).

The percentage yields and chemical determination are in Table I. Fraction 1 recovered about $50 \%$ of total materials and was three or ten times higher in sialic acid content than other fractions. No phosphorus and sialic acid were detectable in Fraction 6 . Freezedried protein of Fraction 3 was red coloured.

Disc gel electrophoretic patterns of each fraction are in Fig. 2. Several bands appeared in the different region of major bands especially in Fractions 3, 4 and 5.

In Fractions 4 and 5, only one or two bands with far less intensity appeared in this region. The intensity of band at the dye front was strong in slower eluting fraction. 


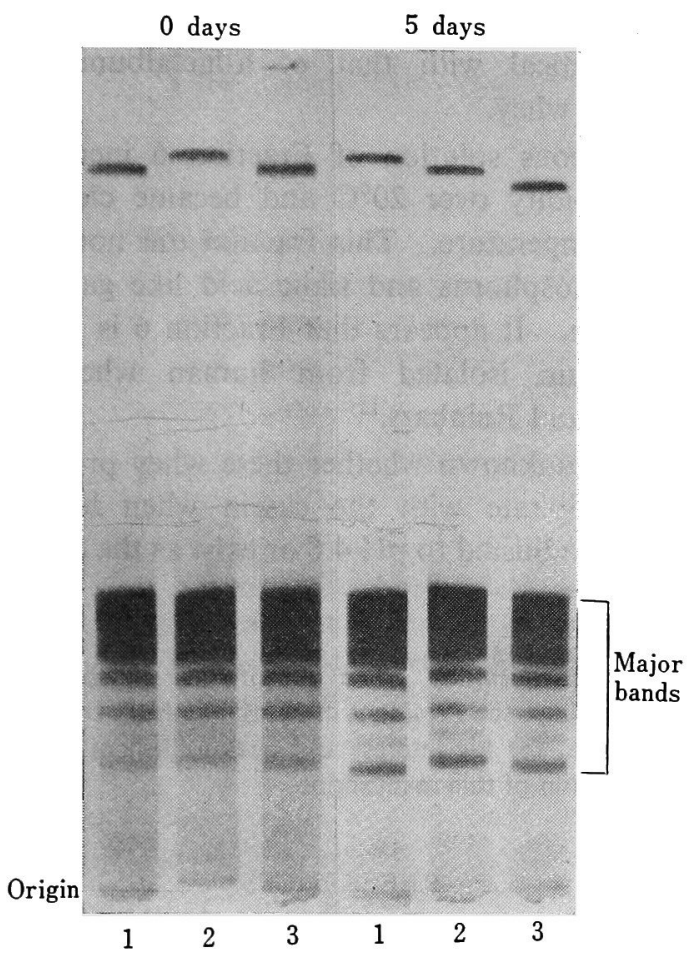

FIG. 3. Disc Gel Electrophoresis of Human Casein Unheated (1) and Heated at $100^{\circ} \mathrm{C}$ for 5 (2) and $10 \mathrm{~min}$ (3) after Storage of 5 Days at $5^{\circ} \mathrm{C}$.

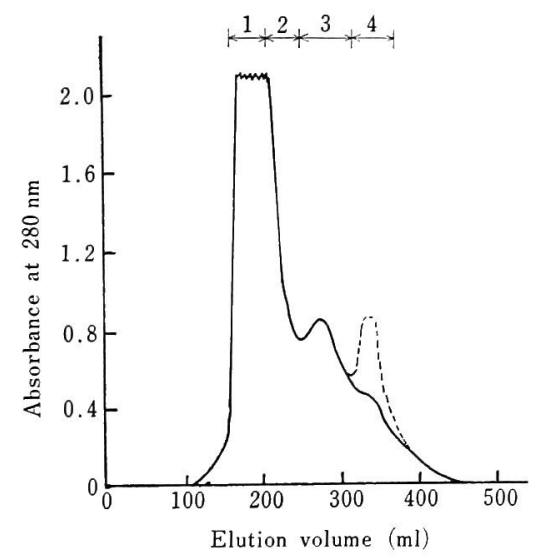

FIG. 4. Elution Pattern Obtained by Gel Filtration of Human Casein Heated at $100^{\circ} \mathrm{C}$ for $5 \mathrm{~min}$ in a Column of Sephadex G-200 at $5^{\circ} \mathrm{C}$.

The electrophoretic band patterns of human casein before gel filtration are in Fig. 3. No different changes of band patterns among the caseins unheated and heated at $100^{\circ} \mathrm{C}$ for 5 and $10 \mathrm{~min}$ were observed. Secondary

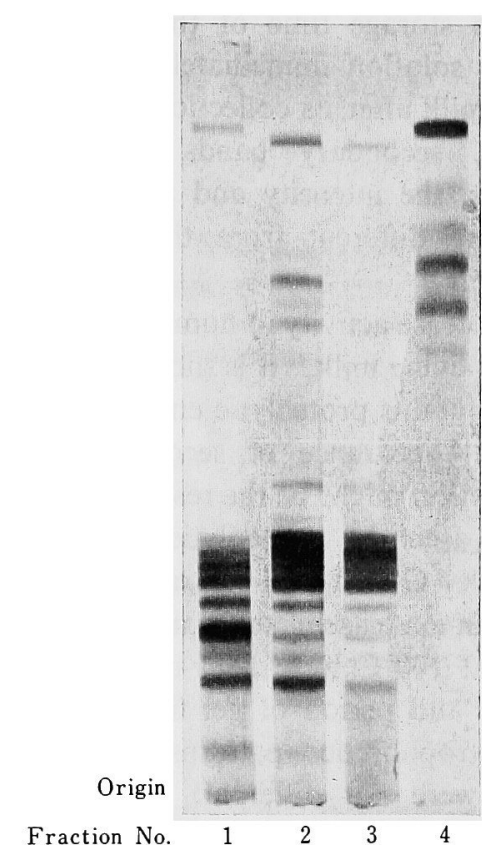

FIG. 5. Disc Gel Electrophoresis of Human Casein Fractions Eluted from Sephadex G-200.

bands other than major bands also appeared with far less intensity at 0 day. These bands increased a little in intensity after storage of 5 days at $5^{\circ} \mathrm{C}$.

Gel filtration pattern of human casein solution heated at $100^{\circ} \mathrm{C}$ for $5 \mathrm{~min}$ is in Fig. 4 . The effluent did not much increase in turbidity at $25^{\circ} \mathrm{C}$ compared with that of unheated casein. Human casein was separated into 4 elution fractions. The electrophoretic patterns of each fraction are in Fig. 5. Secondary bands occurred in Fractions 2, 3 and 4. The intensity of bands in the region of major bands in each fraction was stronger than those in Fig. 2.

\section{DISCUSSION}

On disc gel electrophoretic band pattern of human casein, secondary bands appeared when a casein solution prepared from human skimmed milk was stored at $37^{\circ} \mathrm{C}$ for $5 \mathrm{hr}$. When a casein solution was prepared from human skimmed milk stored at $5^{\circ} \mathrm{C}$, the major bands decreased in intensity and disappeared 
with the storage time of the milk. ${ }^{6}$ When a casein solution immediately prepared from human milk after its collection was chromatographed, secondary bands also appeared. However, the intensity and position of these bands are different from those in previous results. ${ }^{6)}$

As protease activity in human milk is greater than in bovine milk, ${ }^{9}$ it is thought that human casein contains proteolytic enzyme like bovine casein. Appearance of secondary bands in each fraction might be the result of breakdown of the casein by proteolytic enzyme during Sephadex G-200 gel filtration. However, when human casein solutions unheated and heated at $100^{\circ} \mathrm{C}$ were kept at the same temperature and period of gel filtration, changes of electrophoretic patterns among these caseins were not different. From these results, we consider that release of the components in human casein complex causes appearance of secondary bands in each fraction.

Occurrence of the red coloured protein of Fraction 3 suggests the existence of lactoferrin in human casein. Bovine lactoferrin was also separated from the acid precipitated casein fraction by acid extraction of the casein. ${ }^{10)}$

The intensity of band at the dye front is usually observed by disc gel electrophoresis of human casein and whey protein. The intensity of this band markedly increased when a casein solution was chromatographed on a column of Sephadex G-200. This band was also obtained by gel filtration of human casein in a column of Sephadex G-150 by Nagasawa et al. ${ }^{11}$ However, the appearance of secondary bands and increased turbidity of the effluent were not observed. It might be caused by the different conditions of gel filtration of human casein. The mobility of second band in Fraction 5 from the dye front is identical with that of $\alpha$-lactalbumin in human whey.

Aqueous solution of Fraction 6 increased in turbidity over $20^{\circ} \mathrm{C}$ and became clear at low temperature. This fraction did not contain phosphorus and sialic acid like galactothermin. It appears that Fraction 6 is galactothermin isolated from human whey by Shade and Reinhart. ${ }^{12}$

It is unknown whether these whey proteins co-precipitate with the casein when human milk is adjusted to $\mathrm{pH} 4.6$ or exist as the casein complex.

Acknowledgement. The authors are indebted to Mr. I. Ohno, the President of Morinaga Milk Industry Co., Ltd., for his interest and encouragement in the preparation of this manuscript.

\section{REFERENCES}

1) M. L. Groves and W. G. Gordon, Arch. Biochem. Biophys., 140, 47 (1970).

2) T. Nagasawa, I. Kiyosawa and K. Kuwahara, J. Dairy Sci., 54, 987 (1971).

3) F. H. Malpress and F. E. Hytten, Biochem. J, 91, 130 (1964).

4) I. Nishikawa, N. Murata, H. Yoshida and K. Saito, J. Nippon Nogeikagaku Kaishi, 43, 45 (1969).

5) G. F. Vogino and A. Ponzone, Nature, 238, 149 (1972).

6) T. Nagasawa, I. Kiyosawa, K. Kuwahara, Y. Fukuwatari and T. Suzuki, J. Dairy Sci., 55, 289 (1972).

7) R. J. L. Allen, Biochem. J., 34, 558 (1940).

8) L. Warren, J. Biol. Chem., 234, 1771 (1959).

9) G. V. Heyndrickx, Pediatrics, 199, 1019 (1963).

10) M. L. Groves, J. Amer. Chem. Soc., 82, 3345 (1960).

11) T. Nagasawa, I. Kiyosawa, and K. Kuwahara, J. Dairy Sci, 53, 136 (1969).

12) A. L. Schade, and R. W. Reinhart, Biochem. J., 118, 181 (1970). 